Original Article

\title{
PHYTOCHEMICAL SCREENING AND EVALUATION OF ANTIDIARRHOEAL ACTIVITY OF BUNIUM BULBOCASTANUM SEEDS EXTRACT IN EXPERIMENTAL WISTAR RATS
}

\author{
PITAMBAR KHANAL ${ }^{1,2 *}$, NABINA PAUDEL ${ }^{1,3}$, SUSHANT ARYAL ${ }^{4}$, PRAMOD ARYAL ${ }^{5}$ \\ ${ }^{1}$ Department of Pharmacy, Universal College of Medical Sciences, Bhairahawa Nepal, ${ }^{2}$ Lord Buddha Education Foundation, Nepalgunj, \\ Nepal, ${ }^{3}$ Kathmandu University, Department of Pharmacy, Kathmandu, Nepal, ${ }^{4}$ University of Canterbury, New Zealand, ${ }^{5}$ Monash University, \\ Clayton, Australia \\ Email: pitambarkhanal9.pk@gmail.com
}

Received: 17 Oct 2020, Revised and Accepted: 20 Apr 2021

\section{ABSTRACT}

Objective: The main objective of this study was to evaluate the antidiarrheal activity of Bunim bulbocastanum seeds extracts, to exploit the medicinal use of plant in the traditional system of medicine scientifically.

Methods: The adult Wistar albino rats were divided in four groups, i.e. Group M1 (control group) receiving normal saline, group M2 (test group 1) receiving the $250 \mathrm{mg} / \mathrm{kg}$ Bunium bulbocastanum extract, group M2 (test group 2) receiving the $500 \mathrm{mg} / \mathrm{kg}$ Bunium bulbocastanum extract and group M4 (reference) receiving $3 \mathrm{mg} / \mathrm{kg}$ P. 0 Loperamide. Each group of mice with a bodyweight of $1 \mathrm{ml} / 100 \mathrm{~g}$ received castor oil. Mice were sacrificed and the distance traveled by the charcoal meal and the total length of the intestine was then measured. The peristaltic index and percentage of inhibition were calculated by using the formula.

Results: It was found that in the castor oil-induced intestinal transit method extract produced a significant $(\mathrm{p}<0.0001)$ dose-dependent reduction in the distance traveled by charcoal meal comparable to the control peak effect was at the dose of $500 \mathrm{mg} / \mathrm{kg}(\mathrm{PI}=12.06 \pm 3.38)$. Likewise, in the diarrheal dropping test, Bunium bulbocastanum extract causes a significant $(\mathrm{p}<0.05)$ dose-dependent reduction in the number of wet feces i.e. the mean wet of feces was decreased from $2.3 \pm 0.44$ gm to $1.28 \pm 0.36$ gm i.e. significantly different from that elicited by control $(0.80 \pm 0.17 \mathrm{gm})$ $(\mathrm{p}=0.0081)$. However, there were no significant differences in inhibition at a dose of $250 \mathrm{mg} / \mathrm{kg}$ of extract.

Conclusion: This study demonstrated that the crude methanol extract from B. bulbocastanum seeds possesses significant antidiarrheal property and the presence of various secondary metabolites. This justified the antidiarrheal use of plant in the traditional system of medicine.

Keywords: B. bulbocastanum, Phytochemical screening, Anti-diarrheal activity, Methanol extract

(C) 2021 The Authors. Published by Innovare Academic Sciences Pvt Ltd. This is an open access article under the CC BY license (https://creativecommons.org/licenses/by/4.0/) DOI: https://dx.doi.org/10.22159/ijpps.2021v13i6.40035. Journal homepage: https://innovareacademics.in/journals/index.php/ijpps.

\section{INTRODUCTION}

Diarrhea is an alteration of normal bowel movement characterized by an increase in the volume, fluidity, frequency and passage of loose stool at least three times a day. It is a common symptom of gastrointestinal infection due to the number of communicable factors $[1,2]$.

According to the WHO 3-5 billion cases of diarrhea are reported annually, of which 1 billion are less than $5 \mathrm{y}$. As a results, it accounts for $20 \%$ of infant mortality [3, 4]. Especially in developing countries like Nepal, it is an important health problem. So every year Nepal faces an outbreak due to the number of poor health hygiene factors. In year 2000, almost 67,000 people were affected, 371 of whom, died of diarrheal disease. Likewise, in the year 2014, total death from diarrheal disease was 3.89\% [5]. Beside this reality in Nepal, 384 number of species are used to treat diarrhea [6, 7].

Lots of modern technology has been established for the synthesis of new molecules, despite the fact that a number of developing countries still use the herbal-based crude drug for diarrheal treatment [8]. Bunium bulbocastanum is one of the important medicinal plants that grows in mountainous to shurland of Iran, Pakistan, India, Nepal and Afghanistan $[9,10]$. It is an herbaceous perennial plant with typical habitat, i.e. Grows in chalky and rough grassland in arrange of soil from light (sandy), medium (loamy) to heavy (clay) soil [10]. In the indigenous system of medicine seed of $B$. bulbocastanum is regarded as a stimulant and carminative and found to be useful in diarrhea and dyspepsia as well as essential oil fraction of the seed is used in perfumery as a carminative purpose.

Seed propagation and germination ratio is very low because of long seed cycles $[2,4]$. Its plants vary from dwarf $(30 \mathrm{~cm})$ to tall $(80 \mathrm{~cm})$, compact or spreading, moderately to highly branch tuberous. It is a perennial herb, the leaves are freely pinnate, finely dissected and filiform. Flowers are small and white in color $[11,12]$.

B. bulbocstanum traditionally used in the treatment of diarrhea from past decades. So the main aim of the study was to provide scientific justification for the use of Bunium bulbocastanum in modern medicine.

\section{MATERIALS AND METHODS}

\section{Collection and identification of plant material}

The fresh seed of Bunium bulbocastanum $1000 \mathrm{gm}$ was collected in September 2016 from the local market of Bhairahawa and the sample was identified in the Institute of Agricultural and Animal Sciences Paklihawa, Rupandehi, Nepal with a plant identification number (PKH3077).

\section{Preparation of plant material}

The collected seeds were separated from undesirable material. The whole seeds were kept in the shade for drying for three days. After drying, the seed was grounded into powder using an electronic grinder and the final grinded powder was weight.

\section{Chemical and reagent}

Methanol, Ethanol, distilled water, Sulphuric acid, Ferric chloride, Potassium hydroxide, Benzene, Lead acetate Glacial acetic acid, Picric acid, Activated charcoal, Loperamide, Castor oil, Ketamine Diethyl ether, Normal saline, Gum acacia, Sodium hydroxide.

\section{Preparation of plant extract}

The seeds were extracted by maceration. The grinded fruits powder ( $950 \mathrm{gm}$ ) was soaked in methanol for $10 \mathrm{~d}$ in a $2000 \mathrm{ml}$ conical flask 
i.e. 240-250 gm in each flask with $650 \mathrm{ml}$ of methanol in each and mouth of the flask was covered with the aluminum foil. After $10 \mathrm{~d}$, the mixture was filtered, then the filtrate was combined and then concentrated with a rotary evaporator at $40{ }^{\circ} \mathrm{C}$. A black-green methanol extract of $B$. bulbocastanum obtained after concentration.

\section{Phytochemical screening}

A known volume of the sample of B. bulbocastanum was screened for the presence of some secondary metabolites as described for carbohydrates, alkaloids, Steroids, anthraquinones, cardenolides and dienolides, saponin, phenolic compound, flavonoids [13], cardiac glycosides, tannins and triterpenes [14].

\section{Animals}

Wistar albino mice of 73-159 gm of either sex obtained from Banaspati Bibhag, Kathmandu, were used. They were kept in a standardized environmental condition $\left(22 \pm 2.5^{\circ} \mathrm{C}\right)$, humidity $85 \%$, $12 \mathrm{~h}$ light and $12 \mathrm{~h}$ dark cycle and feeded with a standard rodent diet and water. Approval for the use of animals in the study was obtained from the Institute Review Committee of Universal College of Medical Science, Bhairahawa (IRC NO: UCMS/IRC/106/15).

\section{Sample preparation}

Appropriate weight of the extract was taken and the required concentration was made during the experimental process to make the standard solution of concentration $500 \mathrm{mg} / \mathrm{ml}$ and $500 \mathrm{mg} / 2 \mathrm{ml}$.

\section{Preparation of standard}

Loperamide standard solution was made by dissolving the appropriate amount of the drug.

\section{Preparation of activated charcoal solution}

Firstly 10 gm of activated charcoal was weight likewise 5 gm of gum acacia was also weighed. Afterward, the weighed amount of the gum acacia was transferred into the $100 \mathrm{ml}$ volumetric flask and some amount of water was added to the flask to dissolve the gum acacia. And $10 \mathrm{gm}$ of activated charcoal was added to the gum acacia solution and the volume was made up to $100 \mathrm{ml}$.

\section{Castor oil-induced intestinal transit}

Wistar albino rats were divided into four groups in such a way that 4 in each group, contained a total 16 of rats. All animal was fasted for
$24 \mathrm{~h}$ prior to the experiment. Group M1 received distilled water 10 $\mathrm{mg} / \mathrm{kg} \mathrm{P.} \mathrm{0,} \mathrm{group} \mathrm{M2} \mathrm{and} \mathrm{M3} \mathrm{were} \mathrm{treated} \mathrm{with} \mathrm{B.} \mathrm{bulbocastanum}$ extract $250 \mathrm{mg} / \mathrm{kg}$ and $500 \mathrm{mg} / \mathrm{kg}$ P. 0 BBME respectively, whereas group M4 were treated with reference drug loperamide $3 \mathrm{mg} / \mathrm{kg} \mathrm{P}$. 0 . After 40 min castor oil was administered to each mouse by oral administration of a dose of $1 \mathrm{ml} / 100 \mathrm{~g}$ body weight to each mouse. After $30 \mathrm{~min}$ of administration of castor oil, charcoal meal $(10 \%$ activated charcoal in 5\% gum acacia) $1 \mathrm{ml} / 100$ gm body weight was administered to each animal. Then after $30 \mathrm{~min}$ each mouse was sacrificed and the abdominal cavity was dissected and entire small intestine was isolated and the distance travelled by the charcoal meal from the pylorus to the ileocecal junction was measured. The length of the entire small intestine was also measured. The peristaltic index of each rat was calculated by using the following data [15].

$$
\mathrm{PI}=\frac{\mathrm{Lm}}{\mathrm{Lsi}} \times 100
$$

Where $\mathrm{PI}=$ peristaltic index $\mathrm{Lm}=$ length of charcoal meal

Lsi= length of small intestine

$$
\% \text { Inhibition }=\frac{(\text { control-test })}{\text { Control }} \times 100
$$

\section{Castor oil-induced diarrheal drooping test}

Wistar albino rats were divided into four groups in such a way that 4 in each group contained a total 16 of rats. All animals had been fasted for $24 \mathrm{~h}$ prior to the experiment. Group M1 received distilled water $10 \mathrm{mg} / \mathrm{kg} \mathrm{P.} \mathrm{0,} \mathrm{group} \mathrm{M2} \mathrm{and} \mathrm{M3} \mathrm{were} \mathrm{treated} \mathrm{with} B$. bulbocastanum extract $250 \mathrm{mg} / \mathrm{kg}$ and $500 \mathrm{mg} / \mathrm{kg} \mathrm{P.} \mathrm{O} \mathrm{BBME}$ respectively, whereas group M4 were treated with reference drug loperamide $3 \mathrm{mg} / \mathrm{kg}$ P. O. Each animal was placed in an individual cage and the floor of the cage was lined with blotting paper and diarrheal drooping was observed for $4 \mathrm{~h}$. The initial weight and final weight of the filter paper were taken and the mean weight of the feces was calculated and evaluated by subtracting the final weight of filter paper and initial weight of filter paper [16].

\section{RESULTS}

\section{Phytochemical screening}

The analysis of B. Bulbocastanum revealed the presence of tannins, carbohydrates, cardiac glycosides, flavonoids and phenol, while anthraquinones, triterpenes, cardinolide and dienolide were not detected. These observations are summarized in table 1 below.

Table 1: Secondary metabolites of Bunium bulbocastanum seeds

\begin{tabular}{lll}
\hline Secondary metabolite & Observation & Inference \\
\hline Alkaloids & Cream color with Mayer's reagent Reddish-brown precipitate with Wagner's and Dragendorffs reagent. & Not detected \\
Carbohydrate & Presence of violet ring at the junction & Present \\
Tannins & White precipitate with ethanolic KOH & Present \\
Saponins & Stable, persistent froth with water & Present \\
Flavonoids & Dark yellow color with KOH & Present \\
Phenolics & Greenish precipitate with FeCl3. & Present \\
Steroids & Red color with drops of concentrated H2SO4. & Not detected \\
Cardiac glycosides & Presence of reddish-brown color at the interface & Present \\
Anthraquinones & Absence of pink in the ammonical phase. \\
Cardenolides and dienolides & Absence of brown ring at the interface. \\
\hline
\end{tabular}

\section{Castor oil-induced intestinal transit}

The study from castor oil-induced intestinal transit revealed that the methanol seed extract of Bunium bulbocastanum $(250 \mathrm{mg} / \mathrm{kg}$ and 500 $\mathrm{mg} / \mathrm{kg}$ ) produced a significant $(\mathrm{p}<0.0001)$ dose-dependent reduction in the distance travelled by charcoal meal compared to the control. The peak anti-motility effect occurred at a dose of $500 \mathrm{mg} / \mathrm{kg}$ $(\mathrm{PI}=12.06 \pm 3.38)$. This effect was comparable to that produced by standard antidiarrheal drug loperamide (PI=1.34 \pm 1.64$)$.

\begin{tabular}{|c|c|c|c|c|c|c|}
\hline Group & $\begin{array}{l}\text { Castor } \\
\text { oil }\end{array}$ & Treatment & Distance led by charcoal $(\mathrm{cm})$ & Total length of small intestine & Peristaltic index & $\begin{array}{l}\text { P-value } \\
\text { (ANOVA) }\end{array}$ \\
\hline I & + & Distilled Water & $30.28 \pm 4.78$ & $63.63 \pm 6.62$ & $43.43 \pm 5.9$ & - \\
\hline II & + & Loperamide & $0.88 \pm 1.06$ & $65 \pm 8.03$ & $1.34 \pm 1.64^{* *}$ & 0.000092 \\
\hline III & + & $250 \mathrm{mg} / \mathrm{kg}$ & $21.25 \pm 2.90$ & $65.08 \pm 5.28$ & $32.81 \pm 5.4^{* *}$ & 0.000024 \\
\hline IV & + & $500 \mathrm{mg} / \mathrm{kg}$ & $7.38 \pm 1.45$ & $62.28 \pm 9.05$ & $12.06 \pm 3.38^{* *}$ & 0.00051 \\
\hline
\end{tabular}

Table 2: Peristaltic index of the different rat treated with control, loperamide, $250 \mathrm{mg} / \mathrm{kg}$ and $500 \mathrm{mg} / \mathrm{kg}$ of extract

${ }^{* *}$ Indicates the p-value less than 0.0001 as compared to the control group, i.e. highly significant 
Table 3: Mean weight of feces during $4 \mathrm{~h}$ of treatment and percentage inhibition of defecation of the different treatment group of rats

\begin{tabular}{lllll}
\hline Group & Castor oil & Treatment & Meanwt. of feces during 4 h of treatment & Percentage inhibition \\
\hline I & + & DW & $2.34 \pm 0.44$ & - \\
II & + & Loperamide & $0.8 \pm 0.17^{*}$ & 62.88 \\
III & + & $250 \mathrm{mg} / \mathrm{kg}$ & $2.23 \pm 0.20$ & 4.58 \\
IV & + & $500 \mathrm{mg} / \mathrm{kg}$ & $1.28 \pm 0.36^{*}$ & 45.23 \\
\hline
\end{tabular}

*Indicates the p value less than 0.05 as compared to control i.e. highly significant.

\section{Diarrheal drooping test}

During $4 \mathrm{~h}$ after administration of castor oil, all the rats in the control group (distilled water $10 \mathrm{ml} / \mathrm{kg} \mathrm{P.} \mathrm{0)} \mathrm{produced} \mathrm{copious}$ diarrhea. Pretreatment of rats with the methanol seed extract of Bunium bulbocastanum causes a significant $(\mathrm{p}<0.05)$ dosedependent reduction in the amount of wet feces. The reduction exhibit of $500 \mathrm{mg} / \mathrm{kg}$ was higher than the next dose of $250 \mathrm{mg} / \mathrm{kg}$.

At the dose of $500 \mathrm{mg}$, the mean weight of feces decreased from $2.3 \pm 0.44$ gm (as observed in control group) to $1.28 \pm 0.36 \mathrm{gm}$ which is significantly different from that elicited by control $(0.80 \pm 0.17 \mathrm{gm})$, $(\mathrm{p}=0.0081)$. However, there was no significant difference in diarrhea inhibition per $250 \mathrm{mg} / \mathrm{kg}$ of extract.

The highest percentage inhibition of $45.23 \%$ was obtained with the dose of $500 \mathrm{mg} / \mathrm{kg}$ body weight of extract which was comparable to $62.88 \%$ produced by loperamide (table 3 ).

\section{DISCUSSION}

With effective ethnopharmacological value, B. Bulbocastanum is widely used by different tribes as an effective herbal medicine. Literature surveys have revealed that leaves of B. Bulbocastanum are being used for diseases like diarrhea [17]. The study aimed to examine the antidiarrheal effect of B. Bulbocastanum, to ascertain scientific rationales behind its ethnical practice. Our study validates the efficacy of methanol extract of B. Bulbocastanum on the castor oil-induced gastrointestinal transit model. These useful biological activities may be attributed by the presence of bioactive compounds like tannins, flavonoids, alkaloids, glycosides, phenols, steroids, saponins and terpenoids as reported on phytochemical screening.

A lethal dose (LD 50) of the plant extract could not be acquired, as no mortality was detected up to the maximum dose $4000 \mathrm{mg} / \mathrm{kg}$ and the extract was found to be safe with a wide therapeutic range. Therefore, two comparative doses of $250 \mathrm{mg} / \mathrm{kg}$ and $500 \mathrm{mg} / \mathrm{kg}$ were used in in vivo study reported by previous acute toxicity study [17].

Diarrhea results from an imbalance of the absorptive and secretory mechanism within the bowl. In absorptive/osmotic diarrhea a large number of osmotic particles on the gut wall compared with absorptive capacity, whereas in secretory diarrhea, excessive secretion mucosal fluid $[18,19]$. Some studies indicate that in watery diarrhea mortality was mentioned as a major contributing factor i.e. rapid intestinal transit reduces the contact time between absorptive solute and normal epithelium, as well as other contributing factor like 5-HT present in the gut stimulate intestinal motility, secretion and vasodilatation promote for development of diarrhea [20]. In our experiment, extract produced a significant dose-dependent reduction in the amount of wet feces in castor oilinduced intestinal transit test and diarrheal drooping test. Most of the articles mention that ricinolic acid, an active component of castor oil, is responsible for inducing permeability changes in the mucosal membrane and alteration of ion $[4,21,22]$. Besides these purposed mechanisms, castor oil inhibits the intestinal $\mathrm{Na}+\mathrm{and}$ $\mathrm{K}+\mathrm{ATPase}$ activity and stimulates the release of Nitric Oxide (NO) hereby NO causes the release of prostaglandin like PGE2 that are responsible for hypersecretory action [4, 15, 23, 24]. Thus the extract could have been shown an antidiarrheal activity by reducing intestinal permeability or by minimizing hypersecretion.

In the animal experiment, Loperamide was used as a reference drug and sample extract had a statistically comparable effect to the reference drug. It has been reported that loperamide increases the intestinal absorption rate by epithelial cell and also increase intestinal transit time by the slowdown of intestinal motility.
Similarly, in animal model experiment it was found that loperamide inhibits the intestinal secretion induced by E. Coli, and Cholera toxin [25]. Beside this loperamide is an opiate analog, the drug shows its mechanism of action by decreasing the gout muscle tone, decrease the PGE2 mediated fluid secretion, slow down transit time and increase the colonic water absorption $[26,27]$.

When the sample is phytochemically tested, the extract reveals the presence of phytochemical compounds like tannins and flavonoids. Some of the previous study mentions the antidiarrheal activity of Phyto-constituents like tannins and flavonoid [28, 29]. In terms of flavonoid, they may act by inhibition of intestinal motility and hydroelectric secretion to slow down the diarrheal effect [28]. Likewise, tannins is well known for its astringent property, hereby it may cause precipitation of intestinal protein on the intestinal lining as a resultant effect form a protective layer over it with inhibition of toxin from abdomen, which are responsible for diarrheal effect [28, 30]. So this result suggests that these phytochemicals may have contributed to antidiarrheal activity.

\section{CONCLUSION}

The methanol extract of $B$. bulbocastanum seeds showed antidiarrheal activity in several models of diarrheal conditions in test animals. The obtained result thus provided the experimental basis for understanding the use of B. bulbocastanum in traditional medicine as an antidiarrheal agent. Phytochemical screening revealed the presence of various secondary metabolites such as tannins, glycosides, flavonoids and carbohydrates in the seeds of experimental plants.

\section{ACKNOWLEDGEMENT}

We are thankful to Universal College of Medical Sciences Bhairahawa Nepal, Department of Pharmacy for providing the necessary laboratory support to conduct our research work. We are also grateful to Prof. Dr. V. S. Shrivastava H. O. D Department of Pharmacy UCMS Bhairahawa Nepal for his encouragement, inspiration and guidance.

\section{FUNDING}

Nil

\section{CONFLICT OF INTERESTS}

We declare that there is no conflict of interest.

\section{AUTHORS CONTRIBUTIONS}

All the authors are equally contributed

\section{REFERENCES}

1. Tona L, Kambu K, Mesia K, Cimanga K, Apers S, De Bruyne T, et al. Biological screening of traditional preparations from some medicinal plants used as antidiarrhoeal in Kinshasa, Congo. Phytomedicine 1999;6:59-66.

2. Yakubu MT, Nurudeen QO, Salimon SS, Yakubu MO, Jimoh RO, Nafiu MO, et al. Antidiarrhoeal activity of Musa paradisiaca sap in wistar rats. Evid Based Complement Alternat Med 2015;4:1-9.

3. Gilbert A, Herve TT, William YN, Leonard SF, Jules Roger K, Albert K. Antidiarrhoeal and antibacterial activity of aqueous and methanolic leaves extracts of Dissotis thollonii Cogn. (Melastomataceae). Asian Pac J Trop Biomed 2014;4:S672-S8.

4. Rouf R, Uddin SJ, Shilpi JA, Alamgir M. Assessment of antidiarrhoeal activity of the methanol extract of Xylocarpus granatum bark in mice model. J Ethnopharmacol 2007;109:539-42. 
5. Etuk E, Ugwah M, Ajagbonna 0, Onyeyili P. Ethnobotanical survey and preliminary evaluation of medicinal plants with antidiarrhoea properties in Sokoto state, Nigeria. J Med Plant Res 2009;3:763-6.

6. Rokaya MB, Uprety Y, Poudel RC, Timsina B, Münzbergová Z, Asselin $\mathrm{H}$, et al. Traditional uses of medicinal plants in gastrointestinal disorders in Nepal. J Ethnopharmacol 2014;158:221-9.

7. Sahil K, Sudeep B, Akanksha M. Standardization of medicinal plant materials. Int J Res Ayurveda Pharm 2011;2:1100-9.

8. Kumar NR, Vijayasankar G, Prema R, Jeevanandham S, Murthy GL, Sekar M. Prelude studies of the anti-diarrheal activity of ethyl acetate extract of areial part of Indigofera purpurea on isolated rabbit ileum. Asian J Pharm Clin Res 2011;4:85-7.

9. Dar Z, Khan M, Rather M. Effect of age of bulb and spacing on yield and yield attributes of Kalazeera (Bunium persicum. Boiss). Afr J Agric Res 2012;7:6461-4.

10. Emamipoor Y, Maziah M. An efficient method in breaking of dormancy from $B$ unium persicum (Boiss) fedtsch seeds: a valuable herb of middle east and central Asia. Asian Pac J Trop Biomed 2014;4:642-9.

11. Huber H, Stuefer JF, Willems JH. Environmentally induced carry-over effects on seed production, germination and seedling performance in Bunium bulbocastanum (Apiaceae). Flora 1996;191:353-61.

12. Luczaj L, Pieroni A, Tardio J, Pardo-de-Santayana M, Soukand R, Svanberg I, et al. Wild food plant use in 21st century Europe, the disapperance of old traditions and the search for new ciusines involving wild edibles. Acta Soc Bot Pol 2012;81:359-70.

13. Tiwari P, Kumar B, Kaur M, Kaur G, Kaur H. Phytochemical screening and extraction: a review. Int Pharm Sci 2011;1:98106.

14. Hazarika A, Saha D. Preliminary phytochemical screening and evaluation of the anti-diarrhoeal activity of ethanolic extract of leaves of clerodendrum infortunatum. Int J Curr Pharm Res 2017;9:143-6.

15. Adeyemi O, Akindele A, Ogunleye E. Evaluation of the antidiarrhoeal effect of Sanseviera liberica Gerome and Labroy (Agavaceae) root extract. J Ethnopharmacol 2009;123:459-63.

16. Rai A, Sharma P, Barshiliya Y, Sihare M, Negi A. Antidiarrhoeal activity of Rotula aquatica in rats. Asian Pac J Trop Biomed 2012;2:S175-S7.
17. Jamshidi A, Khanzadi S, Azizi M, Azizzadeh M, Hashemi M. Modeling the growth of Staphylococcus aureus as affected by black zira (Bunium persicum) essential oil, temperature, $\mathrm{pH}$ and inoculum levels. Vet Res Forum 2014;5:107.

18. Low Beer T, Read A. Diarrhoea: mechanisms and treatment. Gut 1971;12:1021.

19. Whyte L, Jenkins H. Pathophysiology of diarrhoea. Paediatr Child Health 2012;22:443-7.

20. Camilleri M, Sellin JH, Barrett KE. Pathophysiology, evaluation, and management of chronic watery diarrhea. Gastroenterology 2017;152:515-32. e2.

21. Ali N, Alam H, Khan A, Ahmed G, Shah WA, Nabi M, et al. Antispasmodic and antidiarrhoeal activity of the fruit of Rosa moschata (J). BMC Complement Altern Med 2014;14:1-6.

22. Rahman MS, Akter R, Mazumdar S, Islam F, Mouri NJ, Nandi NC, et al. Antidiabetic and antidiarrhoeal potentials of ethanolic extracts of aerial parts of Cynodon dactylon pers. Asian Pac J Trop Biomed 2015;5:658-62.

23. Adeyemi 0, Akindele A. Antidiarrhoeal activity of the ethyl acetate extract of Baphia nitida (Papilionaceae). J Ethnopharmacol 2008;116:407-12.

24. Prasanth K, Suba V, Ramireddy B, Srinivas B. Evaluation of antidiarrhoeal activity of ethanolic extract of celtis timorensis leaves in experimental rats. Asian J Pharm Clin Res 2014;7:185-8.

25. Theodorou V, Fioramonti J, Hachet T, Bueno L. Absorptive and motor components of the antidiarrhoeal action of loperamide: an in vivo study in pigs. Gut 1991;32:1355-9.

26. Sack RB, Rahman M, Yunus M, Khan EH. Antimicrobial resistance in organisms causing diarrheal disease. Clin Infect Dis 1997;24 Suppl 1:S102-S5

27. Sandhu B, Tripp J, Candy D, Harries J. Loperamide: studies on its mechanism of action. Gut 1981;22:658-62.

28. Umer S, Tekewe A, Kebede N. Antidiarrhoeal and antimicrobial activity of Calpurnia aurea leaf extract. BMC Complement Altern Med 2013;13:1-5.

29. Venkatesan N, Thiyagarajan V, Narayanan S, Arul A, Raja S, Kumar SV, et al. Anti-diarrhoeal potential of Asparagus racemosus wild root extracts in laboratory animals. J Pharm Pharm Sci 2005;8:39-46.

30. Nwafor PA, Bassey AI. Evaluation of anti-diarrhoeal and antiulcerogenic potential of ethanol extract of Carpolobia lutea leaves in rodents. J Ethnopharmacol 2007;111:619-24. 